reduced to $1 \%$ with adequate precaution. With the increasing use of colour developers, especially among amateur photographers who may be unaware of the hazards, we can expect a steady rise in the number of persons developing either the eczematous or the lichenoid type of eruption, and it would be well to be on the look-out for them.

\section{Survival in Hodgkin's Disease}

It is usually taught that a diagnosis of Hodgkin's disease is tantamount to a sentence of death. Even if the disease is first confined to a group of lymph nodes it soon becomes generalized, and death usually occurs within five years. While the initial response to treatment is excellent, it is assumed that recurrence is inevitable and that the lesions ultimately become resistant both to radiotherapy and to cytotoxic agents.

This grim picture has been modified in recent years. In about $12 \%$ of cases the affected tissue shows a predominant infiltration with lymphocytes and there are fewer abnormal reticulum cells than in the classical lesion, though many Sternberg-Reed giant cells are present. This variant is called paragranuloma, ${ }^{1}$ or benign Hodgkin's disease, ${ }^{2}$ and is associated with a ten-year survival rate of $85 \% .^{34}$ About a quarter of these patients develop the classical disease in the course of time. If paragranuloma is treated energetically with radiotherapy cure is possible; otherwise recurrences are likely to occur even after many years of quiescence.

But even in the remaining $88 \%$ of cases of classical Hodgkin's disease the prognosis is extremely variable. The period of survival is related to the extent of the disease. In one series of cases $50 \%$ of patients were alive after five years when the lesions were confined to a single group of lymph nodes or to two adjacent groups. When the disease was generalized the five-year survival-rate was almost nil. ${ }^{5}$ In another series $58 \%$ of patients with localized disease survived for ten years without recurrence after effective radiotherapy. ${ }^{\circ}$

E. C. Easson and M. H. Russell found that $42-45 \%$ of treated patients with localized disease survived ten years without recurrence, but when the disease was generalized only $13 \%$ survived this length of time. ${ }^{7}$ They showed too that among patients with localized disease the rate of mortality declined with time, and the death rate among those who survived ten years was no greater up to the fifteenth year than in the general population. Their conclusion was that patients surviving this length of time without recurrence were probably cured. In a recent review of 42 cases of Hodgkin's disease occurring in childhood F. Kelly has once again shown that with effective radiotherapy the outlook is not hopeless. ${ }^{8}$

\footnotetext{
1 Jackson, H., and Parker, F., New Engl. f. Med., 1944, 230, 1, and 231, 35 and 639 .

- Harrison, C. V., in Recent Advances in Pathology, p. 46, edited by C. V. Harrison, 7th ed., 1960. Churchill, London.

- Dawson, P. J., and Harrison, C. V., f. clin. Path., 1961, 14, 219.

- Brit. med. \%., 1961, 2, 504.

selliffe, A. M., and Thomson, A. D., Brit. F. Cancer, 1955, 9, 21.

* Peters, M. V., and Middlemiss, K. C. H., Amer. F. Roentgenol., 1958, $79,114$.

Easson, E. C., and Russell, M. H., Brit. med. 7., 1963, 1, 1704.

- Kelly, F., Amer. F. Roentgenol., 1965, 95, 48.
}

Of 39 children with the classical disease ten are still alive, seven having survived over five years and three over ten years. The disease runs a somewhat slower course in children than in adults, and at all ages the prognosis is better in females than in males. Kelly believes that as long as the disease remains localized cure is possible after adequate radiotherapy.

While many observers will require a longer period of remission before conceding cure, there can be no doubt that the energetic treatment of localized Hodgkin's disease is often extremely rewarding. The concept that all cases are multifocal in origin is seriously questioned by the excellent results of local irradiation. It is important to be aware that these patients may enjoy many years of complete relief, and that an attitude of fatalistic resignation is no longer necessary.

\section{Beneficent Influence}

The valuable work carried out at the London School of Hygiene and Tropical Medicine is once again the subject of its Annual Report. ${ }^{1}$ From this it appears that the number of students (696) was considerably higher than in the previous year (595), which the Dean, Dr. E. T. C. Spooner, attributes mainly to an increase in the number of courses being offered by the School. For the first time in several years students from the United Kingdom outnumbered those from overseas. There were 364 of them, an increase of $58 \%$ over the previous year. Nine lectureships established by the Ministry of Overseas Development have now all been filled, and six of the lecturers are working abroad-one in Nigeria, two in Kenya, one in Tanzania, one in Geneva, and one in Singapore.

Many individuals, associations, and industrial firms have given generous support to the School, but a specially notable gift this year is $£ 1,000$ from Lady Jameson in mesnory of her husband, the late Sir Wilson Jameson, who was dean of the School from 1931 to 1940 . In this capacity and as professor of public health there he won the highest esteem for his influence on the education of students from all parts of the world and enjoyed the affection of all who met him. The donation is to finance five fellowships enabling past D.P.H. students to visit European countries and study their public health services. Like most academic institutions the School is short of money and accommodation. The housing of its students presents a special problem in that many of them are older than is usual in a university school. Consequently it has joined a company promoted by the London School of Economics with the aim of acquiring properties to let to students on a non-profit-making basis.

At a time when many overseas peoples are becoming sharply conscious of their national identity the School exerts a beneficent influence that reaches beyond textbook education. Members of all creeds and races join there, whether as teachers or as learners, in an endeavour to bring better health to mankind.

\footnotetext{
London School of Hygiene and Tropical Medicine, Report on the
} Work of the School 1964-5, 1965 . London. 